\title{
Feasibility Study of Financial Aspects and Demand of Community to the Construction of the Cempaka Lima General Hospital in Banda Aceh
}

\author{
Brury Apriadi Husaini", Munifah Abdat, Martunis \\ Faculty of Medicine, Syiah Kuala University, Indonesia \\ *bruryapriadi@gmail.com
}

\begin{abstract}
The study of hospital construction efforts is needed for business continuity. Errors in conducting assessments can result in losses to existing capital and resources. This research used a quantitative study with cross sectional design. Financial aspects were analyzed by Payback Period (PP), Net Present Value (NPV), Profitability Index (PI), Internal Return of Rate (IRR), and Average Rate of Return (ARR) methods. Demand of community was analyzed based on the availability of facilities and infrastructure, service quality, tariffs and ownership of health financing sources, as well as access and transportation to hospitals. Results: Based on the analysis of financial aspects, PP was shorter than the life of the investment (10 years), namely 8 years, 1 month and 5 days; Positive NPV of Rp.387,970,363,668, -; PI is 5; IRR is $10.18 \%$; and ARR which is $138 \%$. While the results of public demand found $84 \%$ of respondents chose private and government hospitals, $90 \%$ of respondents conducted examinations at general practitioners, $97 \%$ of respondents chose health services because of complete facilities, $98 \%$ of respondents did blood pressure checks, $97 \%$ of respondents received prescriptions, $90 \%$ of respondents access outpatient services, 59\% of respondents use insurance, and the average distance of respondents from their place of residence to health services is less than $2 \mathrm{~km}(90 \%)$. Hospitals need to increase revenue by adding service products and optimize non-medical revenue to support income and immediately establish operational cooperation with BPJS considering that most of the people who access health services use JKN.
\end{abstract}

Keywords : Feasibility Study, Financial, Demand, Construction, Hospital.

Received May 28, 2020; Revised June 29, 2020; Accepted July 24, 2020 


\section{STRADA Jurnal Ilmiah Kesehatan}

DOI: $10.30994 /$ sjik.v9i2.337

ISSN: 2252-3847 (print); 2614-350X (online)

Vol.9 No.2 November 2020 Page.612-618

\section{BACKGROUND}

Hospital development requires investment feasibility analysis from several aspects, including market, technical, and financial (financial) aspects. Errors in conducting analysis can result in sacrifices / losses on existing capital / resources so a careful assessment is needed before carrying out the construction of the hospital (Hendra, 2013). Business feasibility analysis can be seen from the financial and non-financial aspects. By analyzing the financial aspects, it is known that the business feasibility is related to the capital spent and the profits generated when the business is run. The criteria commonly used to determine financial feasibility are knowing the value of Payback Period (PP), Net Present Value (NPV), Profitability Index (PI), Internal Return of Rate (IRR), and Average Rate of Return (ARR). While the non-financial aspects consist of several aspects including legal aspects, market, technical and technological, management and human resources s, economic and social as well as environmental aspects (Kasmir \& Jakfar, 2012).

Based on PT.Cempaka Lima Utama Profile in 2019, PT.Cempaka Lima Utama is one of the companies engaged in the health sector as a health service provider that will expand the scope of health services by building a class $\mathrm{C}$ public hospital with a capacity of 114 beds in $7,882 \mathrm{~m}^{2}$. This is due to the increasing number of visits to the Cempaka Lima Clinic as a subsidiary of PT.Cempaka Lima Utama where there has been an increasing trend in the number of visits in the last 3 years namely 134,128 in 2017, 152,015 in 2018 and 142,311 from January to November 2019 , according to data from the Banda Aceh Health BPJS branch in the January-June 2019 service there were 19,395 references from the Cempaka Lima Clinic to another hospital in Banda Aceh to receive further services. Thus the development that will be carried out needs to be carried out a feasibility study first so that hospital owners and investors gain confidence that the development is feasible if viewed from the financial and demand aspects of the community. The problem in this study is to see how the feasibility of building a Cempaka Lima General Hospital in terms of financial aspects and how the community demand for the construction of the Cempaka Lima General Hospital.

\section{METHODS}

This research is a quantitative study with a cross-sectional study design. This study uses primary data and secondary data to look at financial aspect and demand of community. This research was carried out on the construction of Cempaka Lima General Hospital and the Public Health Center that working area of Banda Aceh and Cempaka Lima Clinic. The time of the study was conducted in February and June 2020. The study sites were conducted in Public Health Center at Baiturrahman, Banda Raya, Batoh, Jayabaru, Jeulingke, Kopelma Darussalam, Kuta Alam, Kuta Alam, Lampaseh City, Lampuro, Meuraxa, Ulee Kareng and Cempaka Lima Clinic.

Sample in this study are 286 people with criteria, the sampling technique used in this study was non probability sampling. Inclusion criteria for determining the sample is a minimum age of 17 years with the reason that at that age the respondent is able to communicate well and cooperatively, have been treated at least 2 times at the hospital, were at the research location during the study, were willing to be interviewed by signing informed consent. To get data related to financial aspects of the construction of a five-way public hospital, researchers used a database designed in Microsoft Excel that was adopted from a type hospital. This database already has a formula table which can calculate financial aspects gradually. This instrument consists of estimated patient visit rates in 


\section{STRADA Jurnal Ilmiah Kesehatan}

DOI: $10.30994 /$ sjik.v9i2.337

ISSN: 2252-3847 (print); 2614-350X (online)

Vol.9 No.2 November 2020 Page.612-618

2021-2025, summary visits per year, estimated revenue and financing for each service unit in 2021-2025, investment costs, discount factors, and investment analysis (cash flow).

Financial aspects data processing is done with a paper work (Cash Flow) and continued with the Microsoft Excel program. While data processing aspects of community demand that has been collected from the results of data collection is then processed by the stages of coding, editing and processing data. For research articles, the method must contain the type and / or design of the study, the time and location of the study, population and sample, variables, methods data collection for each variable, data analysis methods, and ethical eligibility.

\section{RESULT}

Financial Aspects Analysis

The investment costs for the construction of the Cempaka Lima General Hospital can be seen in the following table:

Table 1. Distribution of investment costs for the construction of the cempaka lima general hospital in banda aceh

\begin{tabular}{clc} 
No & \multicolumn{1}{c}{ Biaya Investasi } & Biaya \\
1 & Soil & Rp. 11.800 .000 .000 \\
2 & Building & Rp. 45.581 .703 .189 \\
3 & Electrical Mechanical & Rp. 16.692 .637 .647 \\
4 & Medical devices & Rp. 10.000 .000 .000 \\
5 & Equipment Administration & Rp. 5.000 .000 .000 \\
& Room & \\
6 & Operational Vehicles & Rp. 1.200 .000 .000 \\
& Total & Rp. 90.274 .340 .836
\end{tabular}

Based on investment costs for the construction of the Banda Aceh Cempaka Lima General Hospital, table 1. obtained the amount of funds/investment capital. The establishment of the Cempaka Lima General Hospital is around Rp. 90.274.340.836.

Table 2. Results of Financial Feasibility Analysis on Development Cempaka Lima General Hospital Banda Aceh

\begin{tabular}{|c|l|c|c|}
\hline No & \multicolumn{1}{|c|}{ Method } & Result & Conclusion \\
\hline 1 & Payback Period (PP) & 8 tahun 1 bulan dan 5 hari & Feasible \\
\hline 2 & Net Present Value (NPV) & Rp. 387.970.363.668,- & Feasible \\
\hline 3 & Profitability Indeks (PI) & 5 & Feasible \\
\hline 4 & Internal Return of Rate (IRR) & $10,18 \%$ & Not Feasible \\
\hline 5 & Average Rate of Return (ARR). & $138 \%$ & Feasible \\
\hline
\end{tabular}

Based on the results of the financial feasibility analysis of the construction of the Banda Aceh Cempaka Lima General Hospital in table 2. it was found that the PP is shorter than the investment life (10 years), namely 8 years 1 month and 5 days; Positive NPV of Rp. 387.970.363.668,- ; PI is 5; IRR is 10.18\%; and ARR which is $138 \%$.

Demand of Community Analysis 


\section{STRADA Jurnal Ilmiah Kesehatan}

DOI: $10.30994 /$ sjik.v9i2.337

ISSN: 2252-3847 (print); 2614-350X (online)

Vol.9 No.2 November 2020 Page.612-618

Table 3. Characteristics of Respondents in Community Health Centers and Cempaka Lima Primary Clinic Banda Aceh in 2020

\begin{tabular}{|c|c|c|c|}
\hline No & Characteristics & $\mathrm{n}$ & $\%$ \\
\hline \multirow[t]{5}{*}{1} & Age & & \\
\hline & $>18-35$ & 88 & 30,8 \\
\hline & $>35-65$ & 183 & 64,0 \\
\hline & $>65$ & 15 & 5,2 \\
\hline & Total & 286 & 100 \\
\hline \multirow[t]{4}{*}{2} & Gender & & \\
\hline & Male & 111 & 38,8 \\
\hline & Female & 175 & 61,2 \\
\hline & Total & 286 & 100 \\
\hline \multirow[t]{6}{*}{3} & Marital Status & & \\
\hline & Married & 243 & 84,9 \\
\hline & Single & 40 & 14,0 \\
\hline & Widow & 1 & 0,3 \\
\hline & Widower & 2 & 0,7 \\
\hline & Total & 286 & 100 \\
\hline \multirow[t]{14}{*}{4} & Public Health Center/Clinic & & \\
\hline & Darussalam & 30 & 10,5 \\
\hline & Ule Kareng & 23 & 8,0 \\
\hline & Lampulo & 30 & 10,5 \\
\hline & Kuta alam & 28 & 9,8 \\
\hline & Cempaka Lima & 35 & 12,2 \\
\hline & Lampaseh & 26 & 9,1 \\
\hline & Jaya baru & 21 & 7,3 \\
\hline & Meuraxa & 7 & 2,4 \\
\hline & Jeulingke & 10 & 3,5 \\
\hline & Baiturrahman & 27 & 9,4 \\
\hline & Banda raya & 26 & 9,1 \\
\hline & Batoh & 23 & 8,0 \\
\hline & Total & 286 & 100 \\
\hline \multirow[t]{11}{*}{5} & Occupation & & \\
\hline & Government Employee & 34 & 11,9 \\
\hline & Entrepreneur & 82 & 28,7 \\
\hline & Student & 11 & 3,8 \\
\hline & Housewife & 66 & 23,1 \\
\hline & Pension & 8 & 2,8 \\
\hline & Fisherman & 1 & 0,3 \\
\hline & Employee & 80 & 28,0 \\
\hline & Businessman & 3 & 1,0 \\
\hline & Household assistant & 1 & 0,3 \\
\hline & Total & 286 & 100 \\
\hline \multirow[t]{3}{*}{6} & Education & & \\
\hline & Elementary school & 1 & 0,4 \\
\hline & Middle school & 23 & 8,0 \\
\hline
\end{tabular}




\section{STRADA Jurnal Ilmiah Kesehatan}

DOI: $10.30994 /$ sjik.v9i2.337

ISSN: 2252-3847 (print); 2614-350X (online)

Vol.9 No.2 November 2020 Page.612-618

\begin{tabular}{|c|c|c|c|}
\hline \multirow[t]{5}{*}{ No } & Characteristics & $\mathrm{n}$ & $\%$ \\
\hline & High school & 121 & 42,0 \\
\hline & Diploma & 78 & 27,6 \\
\hline & Bachelor & 63 & 22,0 \\
\hline & Total & 286 & 100 \\
\hline \multirow[t]{5}{*}{7} & Income & & \\
\hline & $<1$ million & 79 & 27,6 \\
\hline & 1-5 million & 195 & 68,2 \\
\hline & 5-10 million & 12 & 4,2 \\
\hline & Total & 286 & 100 \\
\hline \multirow[t]{6}{*}{8} & Assurance & & \\
\hline & $\begin{array}{l}\text { Jaminan Kesehatan Nasional } \\
\text { (JKN) }\end{array}$ & 270 & 94,4 \\
\hline & Personal insurance & 1 & 0,4 \\
\hline & Jamsostek & 4 & 1,4 \\
\hline & Personal Fee & 11 & 3,8 \\
\hline & Total & 286 & 100 \\
\hline
\end{tabular}

Most respondents had age> 36-65 years as many as 183 people (64.0\%), the sex of the respondents were mostly women as many as 175 people $(61.2 \%)$. Most of the respondents' religion is Islam as many as 286 people (100\%). Most of the marital status is married as many as 243 people $(84.9 \%)$. Darussalam and Lampulo health centers have the most samples, each with 30 people $(10.5 \%)$. Most of the respondents' jobs are selfemployed 82 people $(28.7 \%)$. Most respondents 'education is secondary education as many as 121 people (42.3\%) and most respondents' income is 1-5 million as many as 195 people $(68.2 \%)$ and insurance guarantees used by respondents are mostly JKN as many as 270 people $(94,4 \%)$.

Most $84 \%$ of respondents chose private hospitals and government hospitals compared to other health facilities such as puskesmas, clinics or private doctors' practices. Government hospitals and private hospitals are considered to have its own advantages such as completeness of facilities and medical personnel. Most respondents conducted more examinations at general practitioners, which was $90 \%$, then specialist doctors by $88 \%$, nurses $57 \%$, midwives $42 \%$, and other health workers by $38 \%$.

$97 \%$ of respondents chose health services because of the complete and comfortable facilities. Also supported by health facilities with medical personnel and complete medical equipment by $95 \% .98 \%$ of respondents will do a blood pressure check when they receive health services, while $95 \%$ will do a physical examination, 59\% laboratory tests and $27 \%$ radiological examinations. Most respondents were given a prescription of $97 \%$ when getting health services, in addition to that $92 \%$ of respondents received oral medication compared to injection drug 46\%. Most respondents access outpatient services (90\%) when visiting health services. $70 \%$ sought emergency services, $62 \%$ were hospitalized, and $53 \%$ were laboratory / radiology. 59\% of respondents use insurance when getting health services and $0.9 \%$ spend more than $\mathrm{Rp} 1,000,000$, meaning that there are still respondents who use insurance but still incur costs for getting health services. 


\section{STRADA Jurnal Ilmiah Kesehatan}

DOI: $10.30994 /$ sjik.v9i2.337

ISSN: 2252-3847 (print); 2614-350X (online)

Vol.9 No.2 November 2020 Page.612-618

\section{DISCUSSION}

Hospital development must meet the requirements for location, buildings, infrastructure, human resources, pharmacy, and equipment. The location requirements referred to must meet the requirements regarding health, environmental safety, and spatial planning, as well as in accordance with the results of the study of the needs and feasibility of hospital management. Hospital feasibility study is the result of the analysis and explanation of the feasibility of all aspects that underlie the establishment or development of hospitals, related to the determination of work plans for health services in new and advanced hospitals, in developing or upgrading hospital classes (Kemenkes RI, 2012). Criteria commonly used to determine the feasibility of an investment are Payback Period (PP), Net Present Value (NPV), Internal Rate of Return (IRR), and Profitability Index (PI), and Avarage Rate of Return (ARR) (Kasmir \& Jakfar, 2012)

Payback Period is a period required to recoup investment expenses (initial cash investment) using cash flow, in other words the payback period is the ratio between "initial cash investment" and "cash inflow", the result of which is a unit of time, the value of this ratio is compared with the maximum acceptable payback period (Umar, 2007). The results of research conducted by Arwati \& Sedana (2016) on the development of the Dental and Mouth Hospital of Mahasaraswati University in Denpasar found PPs to be shorter than the construction age of 2 years, 2 months and 53 days so it can be concluded that this project is feasible to be implemented (Arwati, Sedana, \& Artini, 2016). Based on other research conducted by Hendra (2013) on a feasibility study of investment in the construction of the Happy Healthy Hospital in Pekanbaru, it was found that the PP value is 8 years 8 months where the period of return on investment does not exceed the life of the project, so this project is feasible to be implemented (Hendra, 2013).

Net Present Value is the difference between the present value of an investment and the present value of net cash receipts (operational cash flow and terminal cash flow) in the future (Umar, 2007). To calculate the present value, it is necessary to determine the relevant interest rate. NPV> 0 means that the project can create cash inflow with a greater percentage than the opportunity cost of capital invested. If NPV $=0$, the project might be accepted because the cash in flow to be obtained is equal to the opportunity cost of the invested capital. So the greater the NPV value, the better for the project to proceed. The results of research conducted by Sugianto (2013) on the construction of the Unisda Medika hospital in Lamongan based on NPV amounting to Rp.27,349,502,423.12, - so it can be concluded that this project is profitable and feasible to be implemented (Sugianto, 2013).

The Profitability Index method is usually used in the initial stages of evaluating investment planning. According to Giatman (2006), this method emphasizes the value of the comparison between the aspects of benefits (benefits) that will be obtained with aspects of costs and losses that will be borne (cost) in the presence of these investments. benefits are based on the general benefits obtained by the community through the project. Whereas in private projects, benefits are based on the profits obtained by investors from the project (Giatman, 2006). To assess the feasibility of a business or project in terms of PI is if PI $\geq$ 1 , then the investment is feasible and if PI is 1 , then the investment is unfeasible (Giatman, 2006).

This method is used to find the interest rate that equates the present value of expected future cash flows, or cash receipts, by issuing an initial investment (Umar, 2007). IRR is one method for measuring investment levels. The evaluation criteria are if the IRR> of the loan interest, the investment is considered feasible and if the IRR <of the loan interest, then the investment is considered not feasible (Umar, 2007). The results of 


\section{STRADA Jurnal Ilmiah Kesehatan}

DOI: $10.30994 /$ sjik.v9i2.337

ISSN: 2252-3847 (print); 2614-350X (online)

Vol.9 No.2 November 2020 Page.612-618

research conducted by S.A. Hasan, A.D. Albdiri and A.H. Mohsen (2018) in Baghdad, Iraq, on the construction of Al-Qadisiyah University's special surgical hospital showed an IRR of $10.6 \%$ and concluded that the construction was financially feasible to carry out (Hasan, Albdiri, \& Mohsen, 2018).

Avarage Rate of Return (ARR) is a way to measure the average rate of return by comparing the average profit before tax (EAT) with the average investment. The valuation criteria are if the ARR> of the minimum accounting rate of return, then the investment is considered feasible and if the ARR <of the minimum accounting rate of return, then the investment is considered not feasible (Giatman, 2006). The results of research conducted by Irwansyah (2012) on the construction of the Kumala Siwi Kudus Hospital in terms of the financial aspects obtained an average rate of return (ARR) of $41.3 \%$ and can be interpreted as a worthy investment to continue because the average rate of return is greater than the minimum accounting rate of return namely 20\% (Irwansyah, 2012).

\section{CONCLUSION}

Hospitals need to increase revenue by adding service products and optimizing non-medical revenue to support hospital revenue. In the community's demand, even though the community's demand for health services is quite high, the hospital must immediately establish operational cooperation with BPJS considering that most people who access health services use the National Health Insurance.

\section{REFERENCE}

Arwati, N. K. A., Sedana, I. B. P., \& Artini, L. G. S. (2016). Studi Kelayakan Pengembangan Investasi Pada Rumah Sakit Gigi dan Mulut FKG Universitas Mahasaraswati Denpasar. 6, 1459-1484.

Giatman. (2006). Ekonomi Teknik.

Hasan, S. A., Albdiri, A. D., \& Mohsen, A. H. (2018). Feasibility study and economic assessment for al-qadisiyah university hospital of specialized surgeries. International Journal of Civil Engineering and Technology.

Hendra, Y. (2013). Studi kelayakan investasi pembangunan rumah sakit sehat bahagia pekanbaru. Sumber : Http://Etd.Repository.Ugm.Ac.Id/.

Irwansyah. (2012). Analisis kelayakan investasi pada rumah sakit kumala siwi kudus ditinjau dari aspek finansial. E-Jurnal Ekonomi \& Bisnis Unud, 1-17.

Kasmir, \& Jakfar. (2012). Studi Kelayakan Bisnis. Edisi Revisi.

Kemenkes RI. (2012). Pedoman Penyusunan Studi Kelayakan ( Feasibility Study ) Rumah Sakit. 1-17.

Sugianto, D. (2013). Analisis Investasi Pembangunan Rumah Sakit UNISDA Medika di Kampus Universitas Darul Ulum Kecamatan Sukodadi Kabupaten Lamongan.

Extrapolasi Jurnal Teknik Sipil Untag Surabaya, 6, 39-56.

https://doi.org/10.1017/CBO9781107415324.004

Umar. (2007). Studi Kelayakan Bisnis. 